\title{
Photocatalytic Inactivation of Salmonella typhimurium by Floating Carbon-Doped $\mathrm{TiO}_{2}$ Photocatalyst
}

\author{
Sarunas Varnagiris ${ }^{1, *}$, Marius Urbonavicius ${ }^{1}\left(\mathbb{D}\right.$, Sandra Sakalauskaite ${ }^{2}$, Emilija Demikyte ${ }^{2}{ }^{\circledR}$, Simona Tuckute ${ }^{1}$ \\ and Martynas Lelis 1 \\ 1 Center for Hydrogen Energy Technologies, Lithuanian Energy Institute, 3 Breslaujos, \\ 44403 Kaunas, Lithuania; marius.urbonavicius@lei.lt (M.U.); simona.tuckute@lei.lt (S.T.); \\ martynas.lelis@lei.lt (M.L.) \\ 2 Department of Biochemistry, Faculty of Natural Sciences, Vytautas Magnus University, 8 Vileikos, \\ 44404 Kaunas, Lithuania; sandra.sakalauskaite@vdu.lt (S.S.); emilija.demikyte@vdu.lt (E.D.) \\ * Correspondence: sarunas.varnagiris@lei.lt; Tel.: +370-37-401-824
}

check for updates

Citation: Varnagiris, S.; Urbonavicius, M.; Sakalauskaite, S.; Demikyte, E.; Tuckute, S.; Lelis, M. Photocatalytic Inactivation of Salmonella typhimurium by Floating Carbon-Doped $\mathrm{TiO}_{2}$ Photocatalyst. Materials 2021, 14, 5681. https:// doi.org/10.3390/ma14195681

Academic Editors: Rita Giovannetti and Marco Zannotti

Received: 24 August 2021

Accepted: 25 September 2021

Published: 29 September 2021

Publisher's Note: MDPI stays neutral with regard to jurisdictional claims in published maps and institutional affiliations.

Copyright: (C) 2021 by the authors Licensee MDPI, Basel, Switzerland. This article is an open access article distributed under the terms and conditions of the Creative Commons Attribution (CC BY) license (https:/ / creativecommons.org/licenses/by/ $4.0 /)$.

\begin{abstract}
Photocatalysis application is considered as one of the most highly promising techniques for the reduction in wastewater pollution. However, the majority of highly efficient photocatalyst materials are obtained as fine powders, and this causes a lot of photocatalyst handling and reusability issues. The concept of the floating catalyst proposes the immobilization of a photocatalytic (nano)material on relatively large floating substrates and is considered as an encouraging way to overcome some of the most challenging photocatalysis issues. The purpose of this study is to examine floating photocatalyst application for Salmonella typhimurium bacteria inactivation in polluted water. More specifically, high-density polyethylene (HDPE) beads were used as a photocatalyst support for the immobilization of carbon-doped $\mathrm{TiO}_{2}$ films forming floating photocatalyst structures. Carbon-doped $\mathrm{TiO}_{2}$ films in both amorphous and anatase forms were deposited on HDPE beads using the low-temperature magnetron sputtering technique. Bacteria inactivation, together with cycling experiments, revealed promising results by decomposing more than $95 \%$ of Salmonella typhimurium bacteria in five consecutive treatment cycles. Additionally, a thorough analysis of the deposited carbon-doped $\mathrm{TiO}_{2}$ film was performed including morphology, elemental composition and mapping, structure, and depth profiling. The results demonstrate that the proposed method is a suitable technique for the formation of high-quality photocatalytic active films on thermal-sensitive substrates.
\end{abstract}

Keywords: floating photocatalyst; carbon-doped $\mathrm{TiO}_{2}$; thin films; magnetron sputtering; Salmonella typhimurium

\section{Introduction}

In recent decades, environmental pollution and growing wastewater amounts, in particular, have been recognized as essential issues of environmental management and selfsufficient human life. Conventional wastewater treatment technologies (carbon adsorption, flocculation, activated sludge processes, etc.) use physicochemical and biological treatment methods, which, unfortunately, are not capable of decontaminating all types of viruses, bacteria, fungi, or other harmful microorganisms which can be observed in wastewater [1]. Furthermore, these methods require relatively expensive equipment and, in some cases, can cause secondary pollution. Consequently, various alternatives to conventional wastewater treatment technologies are being developed.

Due to their versatile advantages such as high efficiency, eco-friendliness, and ability to decompose various organic molecules, advanced oxidation processes, and photocatalysis in particular, have emerged as some of the most actively researched and developed green wastewater treatment technologies [2]. Still, photocatalysis involves some challenges regarding its application for real-life wastewater cleaning, and they need to be solved. First, most commonly used photocatalysts (e.g., $\mathrm{TiO}_{2}, \mathrm{ZnO}$ ) have relatively wide band 
gaps and require UV light activation or band gap modification. Second, visible (VIS) light and UV light are strongly absorbed by water (only $20 \%$ of initial VIS light flux and about

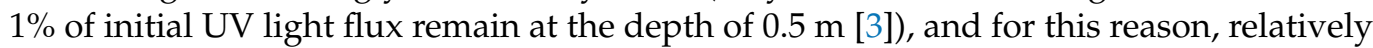
deep traditional wastewater treatment ponds might be an inefficient solution. Third, the form and/or support of photocatalyst material have to be optimized for the performance within a specific treatment system. For example, powder photocatalysts benefit from a larger specific surface area, but it is difficult to extract them from treated wastewater. On the other hand, photocatalytic coatings on traditional sinkable substrates are convenient for handling, but they usually have a low surface area, lack higher efficiency, and suffer from light adsorption by water columns [4,5]. The floating photocatalyst is a relatively new concept which endeavors to immobilize highly efficient photocatalyst materials on lightweight floating substrates. The application of floating photocatalyst particles for the wastewater cleaning process would overcome the two previously mentioned photocatalysis challenges: light intensity weakening in water, and powder/coating handling issues in real-life wastewater cleaning systems.

Thus far, various scientific works have suggested different methods for semiconductor band gap reduction: anionic doping with nonmetals/metal ions/rare-earth ions [6-8], coupling with narrow-band gap semiconductors [9], plasma treatment [10], nanotube formation [11]. Naturally, band gap reduction methods have to be compatible with the selected $\mathrm{TiO}_{2}$ synthesis techniques, and in some cases, particularly when immobilization on substrates is used, this might be challenging. For instance, in photocatalysis experiments, the most often used material is anatase-phase $\mathrm{TiO}_{2}$. In general, crystallization of the anatase phase requires temperatures of $450{ }^{\circ} \mathrm{C}$ or higher. This requirement can be fulfilled by using high-temperature $\mathrm{TiO}_{2}$ synthesis techniques together with the calcination step. Typical examples of such methods are sol-gel [11], hydrolysis-precipitation [11], and solvothermal [12] techniques. However, these methods are hardly compatible with temperature-sensitive substrates such as polystyrene, polyethylene, and other polymers, whereas magnetron sputtering (MS) is a low-temperature technique that can be used for anatase-phase $\mathrm{TiO}_{2}$ synthesis at near room temperatures. Other advantages of the MS process are the possibility to apply different $\mathrm{TiO}_{2}$ doping strategies for the reduction in the band gap, and its high versatility, repeatability, and scalability, amongst others [13-16].

Recently, the use of floating $\mathrm{TiO}_{2}$-based photocatalysts has been considered as an innovative wastewater treatment method. Different types of buoyant substrates and fabrication techniques used for immobilizing $\mathrm{TiO}_{2}$-based photocatalysts on the surface of these substrates have been presented in the literature (see Table 1). The predominant fabrication methods of floating photocatalysts are based on chemical synthesis. Meanwhile, the estimation of photocatalytic performance has been carried out using various dyes as contaminants, and only a few authors tested it with microorganisms (e.g., Escherichia coli, bioaerosols). The application of a floating photocatalyst for bacterial inactivation should be further investigated.

Table 1. Review of recent studies of floating $\mathrm{TiO}_{2}$-based photocatalyst application for the photocatalytic treatment of various compounds.

\begin{tabular}{|c|c|c|c|c|c|}
\hline Substrate & $\begin{array}{l}\text { Fabrication } \\
\text { Technique }\end{array}$ & Photocatalyst & Medium/Light & $\begin{array}{l}\text { Photocatalytic } \\
\text { Performance }\end{array}$ & Ref. \\
\hline Cellulose fabric & $\begin{array}{l}\text { Magnetron } \\
\text { sputtering }\end{array}$ & $\mathrm{TiO}_{2}$ & $\begin{array}{l}\text { Escherichia } \\
\text { coli/UV-LED }\end{array}$ & $100 \% / 1 \mathrm{~h}$ & [17] \\
\hline Pieces of palm trunk & Sol-gel & $\begin{array}{l}\text { Salicylic acid-modified } \\
\text { anatase } \mathrm{TiO}_{2}\end{array}$ & Congo red dye/Sunlight & $98.2 \% / 3.5 \mathrm{~h}$ & [18] \\
\hline Fly ash cenospheres & Sol-gel & Fe-N-co-doped $\mathrm{TiO}_{2}$ & $\begin{array}{l}\text { Rhodamine B/ } \\
\text { Visible light }\end{array}$ & $89 \% / 4 \mathrm{~h}$ & [19] \\
\hline Fly ash cenospheres & $\begin{array}{l}\text { Chemical synthesis } \\
\text { and calcination }\end{array}$ & $\begin{array}{l}\text { Polypyrrole-sensitized } \\
\qquad \mathrm{TiO}_{2}\end{array}$ & $\begin{array}{l}\text { Methylene blue/ } \\
\text { Visible light }\end{array}$ & $55 \% / 9 \mathrm{~h}$ & {$[20]$} \\
\hline $\begin{array}{l}\text { Expanded graphite } \\
\text { C/C composites }\end{array}$ & Sol-gel & $\begin{array}{c}\text { Bismuth/nitrogen-co- } \\
\text { doped } \mathrm{TiO}_{2}\end{array}$ & $\begin{array}{c}\text { Diesel/ } \\
\text { Visible light }\end{array}$ & $83.8 \% / 5 \mathrm{~h}$ & [21] \\
\hline
\end{tabular}


Table 1. Cont.

\begin{tabular}{|c|c|c|c|c|c|}
\hline Substrate & $\begin{array}{l}\text { Fabrication } \\
\text { Technique }\end{array}$ & Photocatalyst & Medium/Light & $\begin{array}{l}\text { Photocatalytic } \\
\text { Performance }\end{array}$ & Ref. \\
\hline Perlite & $\begin{array}{c}\text { Direct } \\
\text { precipitation }\end{array}$ & $\mathrm{TiO}_{2}$ & Phenol/UV-A & $45 \% / 3 \mathrm{~h}$ & {$[22]$} \\
\hline Perlite & $\begin{array}{l}\text { Chemical synthesis } \\
\text { and calcination }\end{array}$ & $\mathrm{TiO}_{2}$ nanoparticles & Furfural/UV-C & $95 \% / 2 \mathrm{~h}$ & [23] \\
\hline Perlite & $\begin{array}{l}\text { Chemical synthesis } \\
\text { and calcination }\end{array}$ & $\mathrm{TiO}_{2}$ & Bioaerosols/UV-C & $40 \% / 2 \mathrm{~h}$ & [24] \\
\hline Perlite & $\begin{array}{l}\text { Chemical synthesis } \\
\text { and calcination }\end{array}$ & $\mathrm{TiO}_{2}$ nanoparticles & Ammonia/UV-C & $68 \% / 3 \mathrm{~h}$ & [25] \\
\hline Perlite & Sol-gel & B-N-co-doped $\mathrm{TiO}_{2}$ & $\begin{array}{l}\text { Rhodamine B/ } \\
\text { Visible light }\end{array}$ & $94 \% / 3 \mathrm{~h}$ & [26] \\
\hline Cellulose paper & $\begin{array}{l}\text { Dipping and } \\
\text { hydrothermal } \\
\text { treatment }\end{array}$ & $\mathrm{TiO}_{2} / \mathrm{Ag}_{2} \mathrm{O}$ composite & Aniline/Visible light & $97 \% / 6 \mathrm{~h}$ & [27] \\
\hline Small pieces of cork & Sol-gel & $\begin{array}{l}\mathrm{TiO}_{2} \text {-polyaniline } \\
\text { composite }\end{array}$ & Methyl orange/Sunlight & $95.2 \% / 3.5 \mathrm{~h}$ & [28] \\
\hline $\begin{array}{l}\text { Low-density } \\
\text { polyethylene }\end{array}$ & 3D printing & $\mathrm{TiO}_{2}$ & Methylene blue/UV & $14 \% / 2 \mathrm{~h}$ & [29] \\
\hline Polystyrene & $\begin{array}{l}\text { Strewing solvent } \\
\text { casting }\end{array}$ & $\mathrm{Ag}^{+}$-doped $\mathrm{TiO}_{2}$ & Methylene blue/UV & $86 \% / 5 \mathrm{~h}$ & [30] \\
\hline
\end{tabular}

In our previous works, we separately demonstrated that MS can be successfully applied for the formation of carbon-doped anatase $\mathrm{TiO}_{2}$ films with a reduced band gap [31], and that photo-active catalyst films can be deposited on temperature-sensitive polymer substrates $[32,33]$. In this work, we combined both approaches and synthesized carbon-doped anatase-phase and amorphous structure $\mathrm{TiO}_{2}$ photocatalysts on high-density polyethylene (HDPE) beads by MS, testing them as floating photocatalysts for Salmonella typhimurium bacteria inactivation. To the extent of our knowledge, this is the first time such a combination of materials and processes has been analyzed. A thorough material analysis, including elemental composition, structure, morphology, chemical bonds, and bacteria membrane permeability, was performed. Additionally, material stability and potential loss of efficiency were evaluated by cycling experiments.

\section{Methodology}

\subsection{Synthesis}

In this study, a physical vapor deposition system (Figure 1) was used to deposit carbon-doped $\mathrm{TiO}_{2}$ films on floating $\mathrm{HDPE}$ beads (obtained from GoodFellow, Huntingdon, UK). The selection of HDPE as a substrate was justified by its appropriate characteristics: nominal bead size $(2-4 \mathrm{~mm})$, density $\left(0.95 \mathrm{~g} / \mathrm{cm}^{3}\right)$, approximate melting point $130{ }^{\circ} \mathrm{C}$, high durability, chemical inertness, low cost, and potential for recyclability. MS was realized using one magnetron with a high-purity Ti target ( $95 \mathrm{~mm}$ diameter, $99.99 \%$ at.). In order to implement $\mathrm{TiO}_{2}$ doping by carbon, the central part of the Ti target (50 mm diameter) was partially engraved and replaced by a carbon disc of corresponding size (10 $\mathrm{mm}$ thickness) which was cut out from the carbon target (99.9\% purity). Prior to the deposition of carbondoped $\mathrm{TiO}_{2}$ films, the base vacuum pressure of $2 \mathrm{mTorr}$ was reached by rotary and diffusion pumps. For the reactive magnetron sputtering process, an $\mathrm{Ar}(5 \%)-\mathrm{O}_{2}$ gas mixture was supplied into the vacuum chamber to maintain a constant pressure of 60 mTorr. HDPE beads were placed directly under the magnetron at a distance of $10 \mathrm{~cm}$ from the Ti target. The carbon-doped $\mathrm{TiO}_{2}$ deposition process was performed using a pulsed DC power supply operating at $260 \mathrm{~W}(0.7 \mathrm{~A})$ and $300 \mathrm{~W}(0.8 \mathrm{~A})$. Increasing the power above $300 \mathrm{~W}$ caused the melting and destruction of HDPE beads. The total duration of the MS deposition process was $16 \mathrm{~h}$. After the first $8 \mathrm{~h}$ of deposition, the HDPE beads were flipped over to 
deposit the carbon-doped $\mathrm{TiO}_{2}$ film on the other side. The approximate thickness of the deposited films was $120 \mathrm{~nm}$ at $260 \mathrm{~W}$ and $150 \mathrm{~nm}$ at $300 \mathrm{~W}$ power.

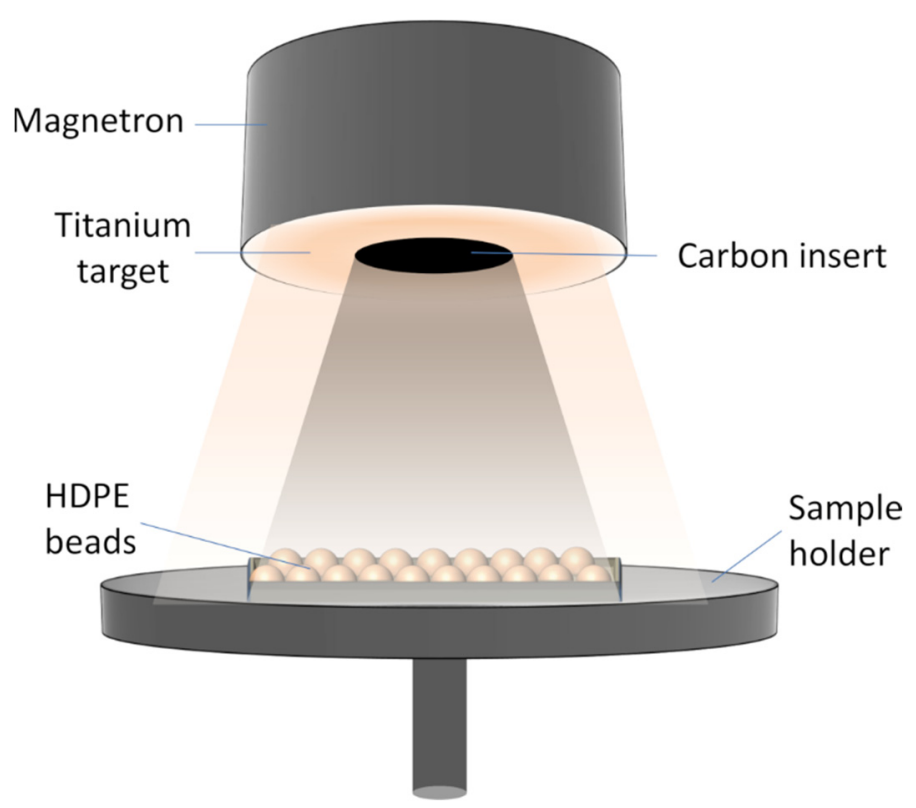

Figure 1. Carbon-doped $\mathrm{TiO}_{2}$ formation scheme.

\subsection{Structural Characterization of the Films}

The crystal structure of the samples was characterized by an X-ray diffractometer operating with $\mathrm{Cu} \mathrm{K} \alpha$ radiation (XRD, Bruker D8, Hamburg, Germany). Carbon-doped $\mathrm{TiO}_{2}$ films were deposited on the flat quartz substrates and HDPE beads under the same conditions simultaneously, and XRD data were collected from flat quartz samples. Crystallite size was estimated by Topas software based on the Scherrer equation with Lorentzian convolution. The surface views of the carbon-doped $\mathrm{TiO}_{2}$ were investigated by a scanning electron microscope (SEM, Hitachi S-3400 N, Tokyo, Japan) using a backscattered electron detector. In addition, elemental mapping was conducted using energy-dispersive $\mathrm{X}$-ray spectroscopy (EDS, Bruker Quad 5040, Hamburg, Germany). Surface elemental analysis and elemental distribution profiles in carbon-doped $\mathrm{TiO}_{2}$ films were measured by an $\mathrm{X}$-ray photoelectron spectroscope (XPS, PHI 5000 Versaprobe, Chanhassen, MN, USA) using monochromated $1486.6 \mathrm{eV}$ Al radiation, $12.5 \mathrm{~W}$ beam power, $50 \mu \mathrm{m}$ beam size, and $45^{\circ}$ measurement angle. XPS depth profile measurement was performed by iterating ion gun sputtering ( $4 \mathrm{kV} \mathrm{Ar}{ }^{+}$ions, 1 min sputtering time) and XPS spectra acquisition after each sputtering step. Sample charging was compensated by a dual-electron low-energy ion neutralization system and fixing the adventitious carbon C $1 \mathrm{~s}$ peak at $284.8 \mathrm{eV}$.

\subsection{Bacteria Inactivation}

\subsubsection{Bacteria Cultivation}

The cultivation of Gram-negative Salmonella enterica ser. Typhimurium SL1344 bacteria was performed by the procedure described in [34]. The only modification of the procedure was that after dilution to an $\mathrm{OD}_{600}$ of 0.15 , overnight bacteria culture was grown to an $\mathrm{OD}_{600}$ of 0.7 instead of $0.8-1.0$.

\subsubsection{Bacteria Inactivation Test}

Bacteria inactivation experiments were implemented in a temperature-controlled vessel at $37^{\circ} \mathrm{C}$. For each experiment, Salmonella typhimurium cells were added to the PBS buffer (pH 7.4). The total volume of the solution was $10 \mathrm{~mL}$. The concentration of bacteria and glucose was $3 \times 10^{9} \mathrm{cfu} / \mathrm{mL}$ and $0.1 \%$, respectively. The total mass of the floating catalyst was $1 \mathrm{~g}$ per experiment. The treatment time for the UV-B lamp (intensity 
$5 \mathrm{~mW} / \mathrm{cm}^{2}$, PL-S 9W/01/2p 1CT, Philips, Amsterdam, Netherlands) was $1 \mathrm{~h}$. Two types of control samples (without HDPE beads and light irradiation) were used.

After treatment, the viability of the bacteria was evaluated by the spread plate method. The main parameters of the procedure were as follows: used sample volume $-50 \mu \mathrm{L}$; sample dilution-1:2500; incubation medium-LB Agar; incubation time-20-22 h, with an incubation temperature of $37^{\circ} \mathrm{C}$. The remaining part of the treated bacteria suspensions was used for the measurement of membrane permeability by the N-phenyl-1-naphthylamine (NPN) uptake factor assay (more details on the used procedure are provided in [35]).

\section{Results and Discussion}

Figure 2 shows XRD patterns of carbon-doped $\mathrm{TiO}_{2}$ films deposited on the surface of HDPE beads using $260 \mathrm{~W}$ and $300 \mathrm{~W}$ magnetron power. MS using a lower power (260 W) resulted in the formation of amorphous carbon-doped $\mathrm{TiO}_{2}$. The observation of amorphous $\mathrm{TiO}_{2}$ is not extraordinary and, traditionally, is attributed to the too low temperature of the sample during the deposition process which, in turn, depends on the magnetron power. Some of the previous studies reported that temperatures above $300^{\circ} \mathrm{C}$ are required for the growth of crystalline anatase instead of amorphous films [36]. However, others suggested that such high temperatures are not necessary and that they might be compensated by other factors. The study of J. Musil et al. revealed a close relationship between the $\mathrm{TiO}_{2}$ surface temperature during the deposition process, film deposition rate, and its crystalline phase formation [37]. According to this study, only a $160^{\circ} \mathrm{C}$ surface temperature is required to form anatase-phase $\mathrm{TiO}_{2}$, but the deposition rate should be relatively low (approximately $5 \mathrm{~nm} / \mathrm{min}$ ). Additionally, it was demonstrated that during the $\mathrm{TiO}_{2}$ film deposition process, the actual temperature of the growing surface can be significantly higher (by more than $100{ }^{\circ} \mathrm{C}$ ) than the temperature of the substrate. These findings comply with our results since a crystalline film was successfully formed using $300 \mathrm{~W}$ magnetron power, and the temperature-sensitive HDPE substrate remained stable without any degradation of the structure. Still, excesses of $300 \mathrm{~W}$ deposition power significantly increased the HDPE substrate temperature and were responsible for the HDPE melting process.

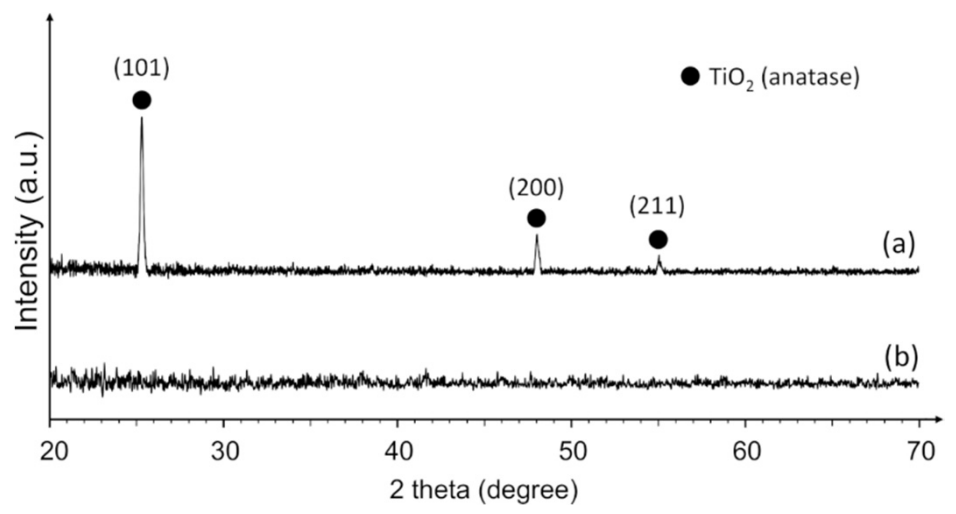

Figure 2. XRD pattern of (a) crystalline and (b) amorphous carbon-doped $\mathrm{TiO}_{2}$ films deposited on the surface of HDPE beads using $300 \mathrm{~W}$ and $260 \mathrm{~W}$ magnetron power, respectively.

It was determined that the crystalline phase obtained by $300 \mathrm{~W}$ deposition corresponds to the anatase form of $\mathrm{TiO}_{2}$ (tetragonal, $\mathrm{I} 41 / \mathrm{amd}$ ). The average crystallite size was estimated at $38 \mathrm{~nm}$. XRD did not detect any peaks which would be attributed to graphite or any other carbon-containing crystal phase. Additionally, presumably due to the insufficient carbon concentration (see XPS results), the XRD pattern suggests that carbon dopants did not have any significant effects on the anatase structure. This result confirms the formation of a regular $\mathrm{TiO}_{2}$ anatase phase which is the most common photocatalytic surface. Similar results were observed by other authors, who used the MS technique for undoped anatase and anatase $/$ rutile $\mathrm{TiO}_{2}$ film deposition onto various temperature-sensitive substrates [38-40]. 
Surface morphology and elemental mapping analyses of carbon-doped $\mathrm{TiO}_{2}$ films deposited on HDPE beads were performed using SEM and EDS techniques, and the results are shown in Figure 3 (a and c amorphous, and $\mathrm{b}$ and $\mathrm{d}$ anatase-phase carbon-doped $\mathrm{TiO}_{2}$ ). The SEM surface images (Figure $3 a, b$ ) reveal that both the amorphous and anatase-phase carbon-doped $\mathrm{TiO}_{2}$ films repeated the HDPE surface texture. However, some cracks and slivers were observed as well (inserts of Figure $3 a, b)$ ). A slightly higher concentration of cracks and slivers can be observed by analyzing the anatase-phase carbon-doped $\mathrm{TiO}_{2}$ films (Figure $3 b$ ) compared to the amorphous $\mathrm{TiO}_{2}$ films (Figure 3a). This might be related to the higher MS deposition process power and higher HDPE surface temperature. Our previous studies revealed that temperature-sensitive polymers such as EPS or HDPE have a very clear temperature limit. Below these limits, polymers remain remarkably stable, but even a very small increment in the temperature above the limit can cause polymer shrinkage or induce other structural changes [32]. This study reveals that with the used experimental setup, the HDPE temperature limit is reached slightly above $300 \mathrm{~W}$ magnetron power. Therefore, we presume that the increase in cracks in the anatase phase of carbon-doped $\mathrm{TiO}_{2}$ films indicates the approach of the specific temperature limit for HDPE beads.
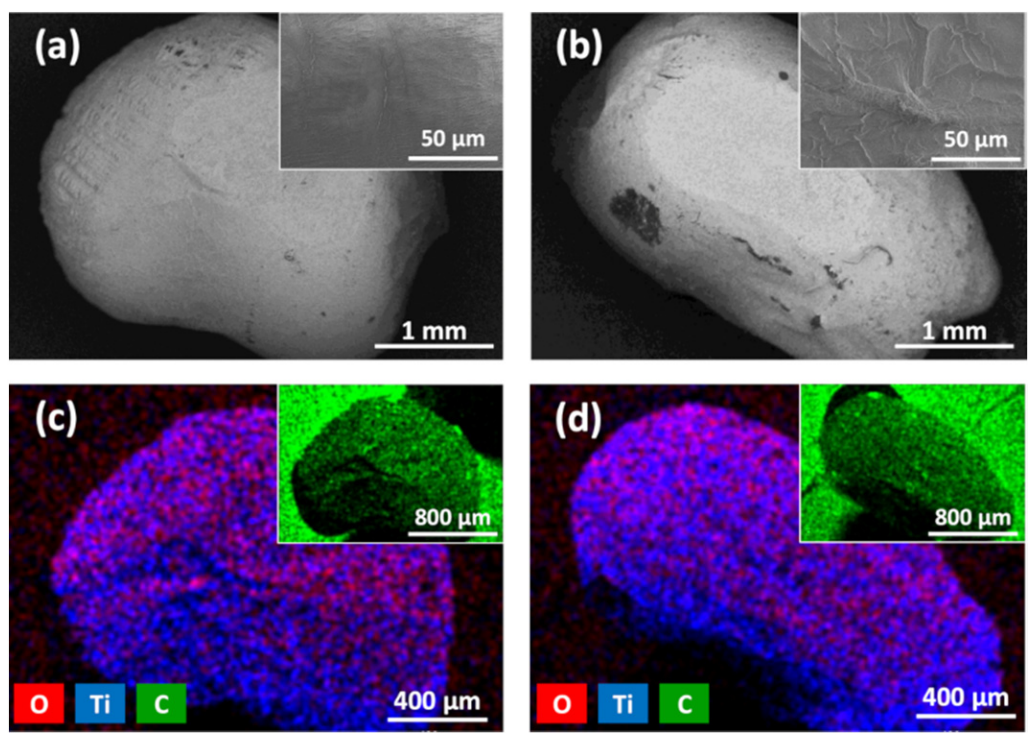

Figure 3. SEM surface images and EDS elemental mapping views of $(\mathbf{a}, \mathbf{c})$ carbon-doped amorphous $\mathrm{TiO}_{2}$ and $(\mathbf{b}, \mathbf{d})$ carbon-doped anatase $\mathrm{TiO}_{2}$ films deposited on HDPE beads.

EDS elemental analysis and mapping of the films were performed in order to identify all the elements and examine their distribution. EDS analysis observed the existence of three elements: carbon, oxygen, and titanium. Although carbon is a dopant and is present in the films, it is also the main element of the HDPE $\left(-\left(\mathrm{CH}_{2}-\mathrm{CH}_{2}\right) n-\right)$ - and carbon-based sticking pad which was used for the immobilization of HDPE beads during SEM/EDS analysis (inserts of Figure 3c,d). Oxygen and titanium showed a relatively uniform distribution over the surface of the HDPE beads (Figure $3 c, d$ ), confirming uniform $\mathrm{TiO}_{2}$ deposition in both the amorphous and anatase carbon-doped $\mathrm{TiO}_{2}$ films.

Similarly, XPS survey analysis also confirmed that the amorphous and anatase carbondoped $\mathrm{TiO}_{2}$ films consisted of the $\mathrm{Ti}, \mathrm{O}$, and $\mathrm{C}$ elements without any other impurities (Figure 4). Figure 5a,b represent almost identical high-resolution $\mathrm{O} 1 \mathrm{~s}$ and Ti $2 \mathrm{p}$ spectra of amorphous and anatase carbon-doped $\mathrm{TiO}_{2}$. Despite the completely different crystallinities of the samples (Figure 2), Ti 2p XPS spectra consisted of two peaks, Ti $2 p 3 / 2$ and Ti $2 p$ $1 / 2$, at $458.6 \mathrm{eV}$ and $464.3 \mathrm{eV}$, respectively, with $5.7 \mathrm{eV}$ peak separation, which confirms the presence of the $\mathrm{TiO}_{2}$ compound in either case [41]. 


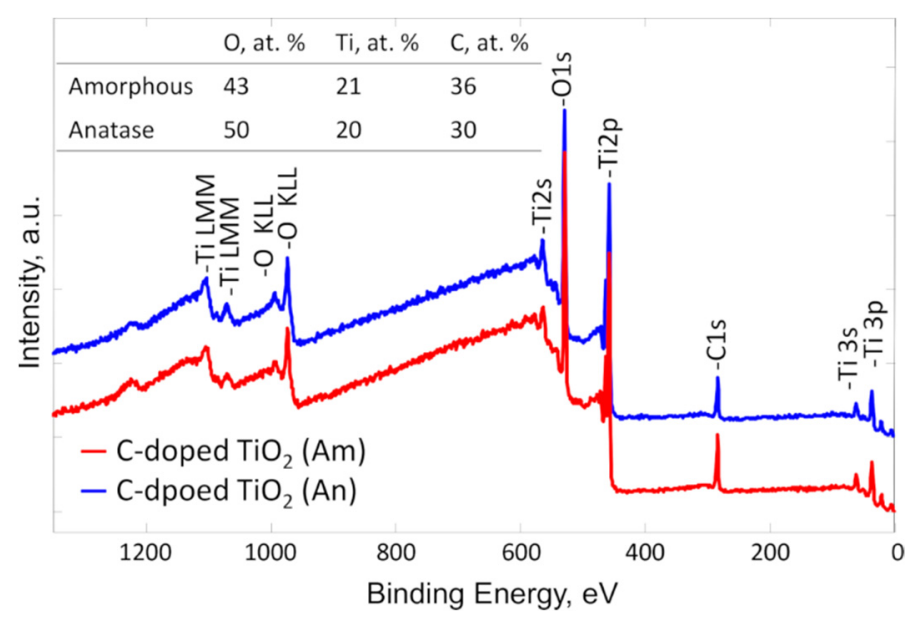

Figure 4. XPS survey spectra and elemental composition of C-doped $\mathrm{TiO}_{2}$ amorphous (red line) and C-doped $\mathrm{TiO}_{2}$ anatase (blue line).
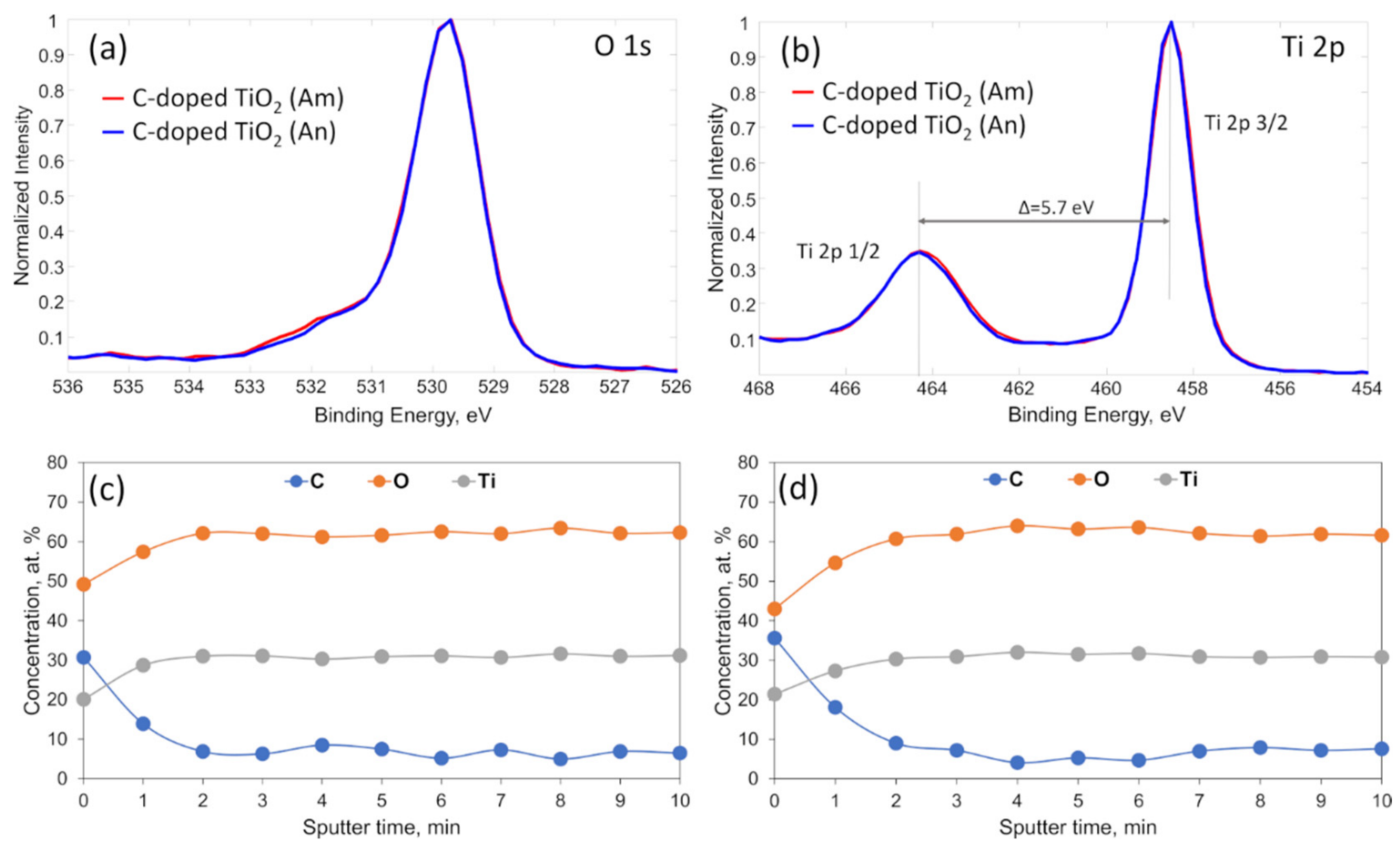

Figure 5. (a) O1s and (b) Ti2p XPS spectra of amorphous (red) and anatase (blue) carbon-doped $\mathrm{TiO}_{2}$ films, and depth profiles of (c) anatase and (d) amorphous carbon-doped $\mathrm{TiO}_{2}$ films.

Figure $5 c, d$ include the XPS depth profiles of anatase and amorphous carbon-doped $\mathrm{TiO}_{2}$ films, respectively. Films were sputtered for $10 \mathrm{~min}$ with a $1 \mathrm{~min}$ step, and the quantitative distribution of $\mathrm{C}, \mathrm{O}$, and Ti through the films was estimated. At the very top of the anatase film surface, the amount of $\mathrm{O}$, Ti, and $\mathrm{C}$ was approximately 50 at. \%, 20 at. $\%$, and 30 at. \%, respectively, while the amorphous film surface included 43 at. $\%$ O, 21 at. $\% \mathrm{Ti}$, and 36 at. \% C (Figure 4). The enlarged carbon concentration at the top surface can be attributed to the naturally formed thin layer of adventitious carbon (carbon/hydrocarbon layer due to the exposure to the atmosphere). This can be confirmed by analyzing the $\mathrm{O} 1 \mathrm{~s}$ spectra in Figure 5a, which involves both amorphous (red) and anatase (blue) spectra. It can be seen that both films have a shoulder at binding energies between 531 and $533 \mathrm{eV}$. Still, the amorphous film (red) has a slightly higher shift to the left side than anatase. This shows that the amorphous film includes a higher amount of carbon compared to anatase and confirms the result, which was observed at the top layer by performing depth profile 
measurement. The $\mathrm{O}$ 1s components at this region are generally attributed to the various carbon oxide bonds and adsorb moisture [42]. In deeper layers of the films, the $\mathrm{O}$ and $\mathrm{Ti}$ concentrations increased slightly, and the $\mathrm{O} / \mathrm{Ti}$ ratio reached a nearly stoichiometric value of 2. The depth profiles confirm that in situ carbon doping resulted in a sufficiently homogeneous carbon distribution, varying between approximately 5 and 7 at. \% in both the anatase and amorphous films.

The photocatalytic activity of the carbon-doped $\mathrm{TiO}_{2}$ floating photocatalysts was estimated by measuring the viability of Salmonella enterica cells in an aqueous solution under UV-B irradiation (Figure 6a). The influence of UV-B irradiation on bacteria without any photocatalyst showed that viability decreased by approximately $50 \%$ after $1 \mathrm{~h}$ of exposure. It is important to mention that this value remained relatively stable even after a longer treatment time. Meanwhile, during the first run with UV-B light and floating carbon-doped $\mathrm{TiO}_{2}$ photocatalysts, bacteria viability decreased to approximately $19 \%$ and $2 \%$, for the amorphous and anatase phases, respectively. Consecutive tests with the same photocatalyst and a new dose of bacteria solution showed an even higher Salmonella enterica inactivation rate, displaying reduced viability at approximately $1-3 \%$. These values remained stable in all further runs, exposing our synthesized floating photocatalyst potential for multiple bacteria inactivation applications. O. Akhavan et al. investigated bacteria inactivation and their proliferation after the destruction process using $\mathrm{TiO}_{2}$-based photocatalysts [43-45]. They showed that the sufficient viability of bacteria is $10 \%$ to resume their proliferation. On the other hand, viability of less than $10 \%$ stops bacteria proliferation and has practical importance in general.

Additionally, to distinguish the difference between the results using amorphous and anatase carbon-doped $\mathrm{TiO}_{2}$ photocatalysts, we calculated the total amount of bacteria in our samples (CFU/mL) and compared the log reduction in the pathogen (insert in Figure 6a). The obtained results of five consecutive runs show increasing bactericidal efficiency of carbon-doped $\mathrm{TiO}_{2}$ (An) during the first three runs and its stabilization for the last two runs. Meanwhile, the carbon-doped $\mathrm{TiO}_{2}(\mathrm{Am})$ effectivity against Salmonella enterica bacteria was stable during the first three runs, and the highest effect was obtained during the fourth run. The fifth run was less effective but not worse than the first three. In comparison with control samples, carbon-doped $\mathrm{TiO}_{2}(\mathrm{Am})$ decreased the viability of $S$. enterica cells by $1.5 \mathrm{log}$ and carbon-doped $\mathrm{TiO}_{2}(\mathrm{An})$ by $2.5 \mathrm{log}$. This means that the reduction in the pathogen was approximately $90 \%$ and $99 \%$ for the amorphous and anatase carbon-doped $\mathrm{TiO}_{2}$ photocatalysts, respectively. The bactericidal effect induced by UV light-irradiated undoped anatase $\mathrm{TiO}_{2}$ deposited on the HDPE beads was investigated in our previous paper [35]. In the case of undoped $\mathrm{TiO}_{2}$, the inactivation efficiency of bacteria averaged $97 \%$, which is higher than the amorphous but lower than the anatase carbon-doped $\mathrm{TiO}_{2}$ photocatalyst. Moreover, after the first run, bacterial viability was $6.3 \%$ with undoped $\mathrm{TiO}_{2}$, while viability decreased to $1.7 \%$ with anatase carbon-doped $\mathrm{TiO}_{2}$. Generally, it can be stated that the obtained photocatalytic performance is more or less similar or even higher in comparison with that achieved by other authors (Table 1).

Additionally, we determined the permeability of the $S$. enterica bacteria membrane after bacteria treatment by UV-B irradiation and $\mathrm{TiO}_{2}$ photocatalysts (Figure 6b). Polymyxin $\mathrm{B}$ (PMB) was used as a control value for the dead cells. The NPN uptake factor in that sample was approximately 3 , whereas in a control sample, it was equal to 1 . UV-B irradiation alone increased the NPN uptake factor value up to 1.3. The calculated average values of membrane permeability using UV-B-irradiated carbon-doped anatase-phase $\mathrm{TiO}_{2}(\mathrm{An})$ and amorphous $\mathrm{TiO}_{2}(\mathrm{Am})$ photocatalysts were approximately 1.5 and 1.2, respectively. The value of 1.2 for the carbon-doped $\mathrm{TiO}_{2}(\mathrm{Am})$ photocatalyst might be related to the generation of a lower amount of reactive oxygen species (ROS) compared to the anatasephase carbon-doped $\mathrm{TiO}_{2}$ photocatalyst, and to the fact that photocatalyst beads might shield bacteria from the intensive light. Both anatase and amorphous films generate external ROS, which cause the production of intracellular ROS. These internal ROS are the cause of bacteria degradation. On this topic, the following article may be useful [33]. 
DCFH-DA is a cell-permeant reagent fluorogenic dye that measures hydroxyl, peroxyl, and other ROS activity in the cell. We are not able to specify which exact group of ROS is formed in bacteria and the reason for its degradation. Still, both types of photocatalyst demonstrated their potential to be used for the successful inactivation of $S$. enterica bacteria from polluted water even after five cycles.

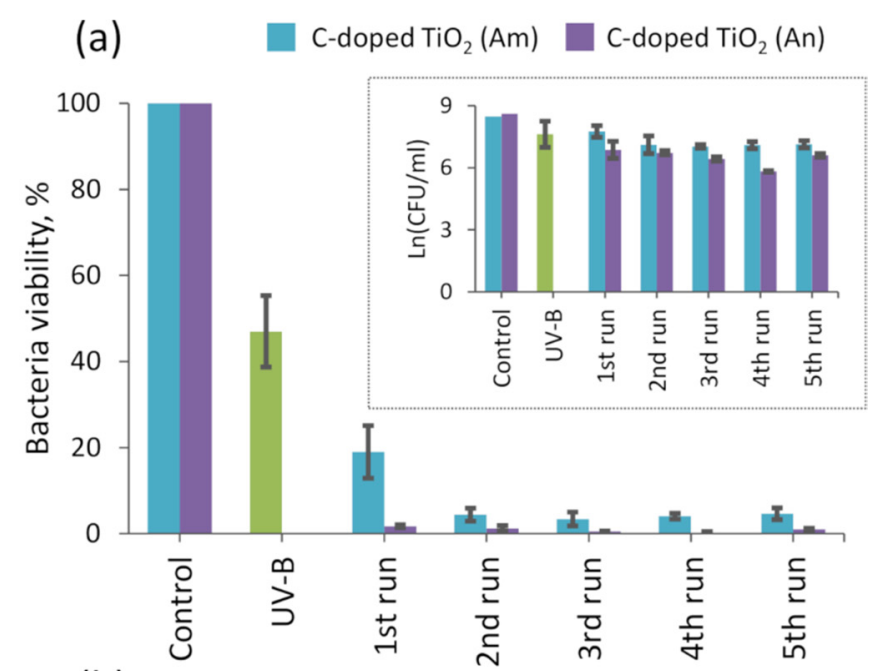

(b)

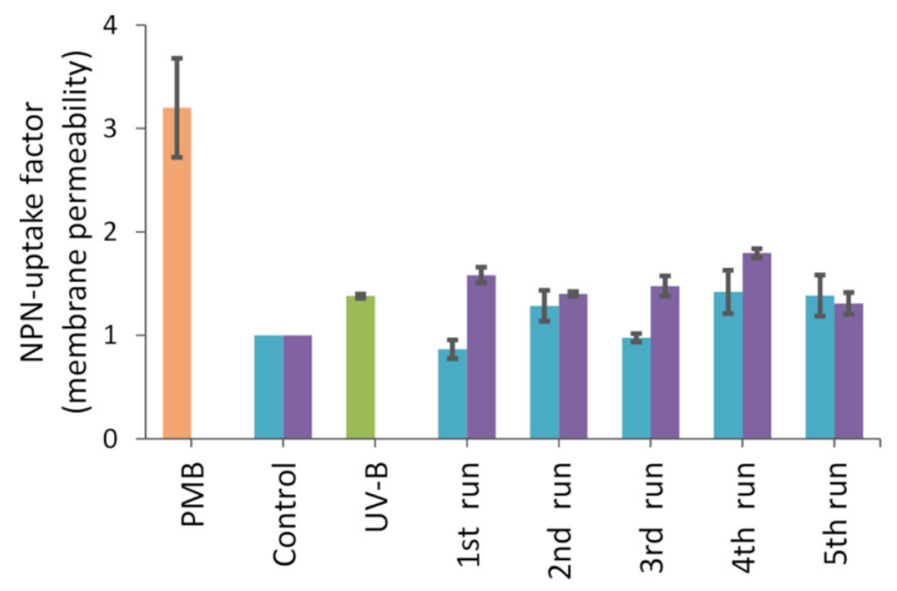

Figure 6. Results of cyclic photocatalytic bacteria treatment by floating carbon-doped $\mathrm{TiO}_{2}$ photocatalysts under UV-B irradiation: (a) Salmonella typhimurium SL1344 bacteria viability; (b) NPN uptake factor (membrane permeability).

\section{Conclusions}

This study presents the results of carbon-doped $\mathrm{TiO}_{2}$ thin film deposition on HDPE beads by magnetron sputtering and their usage as floating photocatalysts for bacteria inactivation. The carbon doping and $\mathrm{TiO}_{2}$ deposition processes were performed simultaneously using a customized magnetron target design. Two types of carbon-doped $\mathrm{TiO}_{2}$ films were obtained using a pulsed DC power supply operating at $260 \mathrm{~W}(0.7 \mathrm{~A})$ and $300 \mathrm{~W}(0.8 \mathrm{~A})$.

With the lower $(260 \mathrm{~W})$ magnetron sputtering power, an amorphous carbon-doped $\mathrm{TiO}_{2}$ film was obtained. Crystallization is closely related to the sample surface temperature during the deposition process. Accordingly, an increase in the sputtering power is a natural step to enhance the crystallization of a film. However, the conducted experiments showed that there is only a small range of the appropriate magnetron sputtering power (in our case, approximately $300 \mathrm{~W}$ ) that is high enough for the crystallization of the carbon-doped $\mathrm{TiO}_{2}$ film without melting the HDPE beads which are used as a substrate. Except for several 
cracks, morphology analysis by SEM did not indicate any significant differences between the amorphous and anatase-phase carbon-doped $\mathrm{TiO}_{2}$ films on the HDPE beads.

Although XRD observed a completely different structure of the carbon-doped $\mathrm{TiO}_{2}$ samples deposited at different power levels, XPS analysis confirmed the formation of the $\mathrm{TiO}_{2}$ compound in both cases. The depth profiles of the samples indicated that, throughout the film, the $\mathrm{O} / \mathrm{Ti}$ ratio was nearly 2 , and the average carbon content varied in the range between 5 and 7 at. $\%$.

Amorphous and anatase-phase carbon-doped $\mathrm{TiO}_{2}$ floating photocatalysts were used for the Salmonella enterica inactivation tests. The viability of bacteria decreased to approximately $19 \%$ and $2 \%$ after the first run, while all further runs showed viability of $3 \%$ and $1 \%$ with amorphous and anatase carbon-doped $\mathrm{TiO}_{2}$ photocatalysts, respectively. It can be concluded that anatase carbon-doped $\mathrm{TiO}_{2}$ showed slightly better inactivation results as well as higher bacteria membrane permeability than amorphous carbon-doped $\mathrm{TiO}_{2}$ after five runs. However, both the amorphous and anatase carbon-doped $\mathrm{TiO}_{2}$ floating photocatalysts demonstrated their practical ability to be used for bacteria inactivation in polluted water.

Author Contributions: Conceptualization and supervision, M.L.; methodology, M.U. and S.V.; investigation, S.S., S.T., S.V., M.U. and E.D.; writing—original draft preparation, M.U., S.V. and S.S.; writing-review and editing, S.V., M.U., S.S. and M.L.; visualization, S.T., M.U. and S.V. All authors have read and agreed to the published version of the manuscript.

Funding: This research is funded by the European Social Fund according to the activity "Improvement of researchers' qualification by implementing world-class R\&D projects" of Measure No. 09.3.3LMT-K-712, project "Investigation of the application of $\mathrm{TiO}_{2}$ and $\mathrm{ZnO}$ for the visible light assisted photocatalytical disinfection of the biologically contaminated water" (09.3.3-LMT-K-712-01-0175).

Institutional Review Board Statement: Not applicable.

Informed Consent Statement: Not applicable.

Data Availability Statement: Not applicable.

Acknowledgments: The authors express gratitude to Darius Milcius and Albinas Svirskis for their input in material synthesis; Rimantas Daugelavicius and Neringa Kuliesiene for their input in data analysis and interpretation; and Mindaugas Aikas, Rolandas Uscila, and Deimante Vasiliauske for their valuable input in preparing and performing the photocatalysis-based experiments.

Conflicts of Interest: The authors declare no conflict of interest.

\section{References}

1. Letifi, H.; Dridi, D.; Litaiem, Y.; Ammar, S.; Dimassi, W.; Chtourou, R. High efficient and cost Effective titanium doped tin dioxide based photocatalysts synthesized via co-precipitation approach. Catalysts 2021, 11, 803. [CrossRef]

2. Rueda-Marquez, J.J.; Levchuk, I.; Fernández Ibañez, P.; Sillanpää, M. A critical review on application of photocatalysis for toxicity reduction of real wastewaters. J. Clean. Prod. 2020, 258, 120694. [CrossRef]

3. Shan, A.Y.; Ghazi, T.I.M.; Rashid, S.A. Immobilisation of titanium dioxide onto supporting materials in heterogeneous photocatalysis: A review. Appl. Catal. A Gen. 2010, 389, 1-8. [CrossRef]

4. Rajbongshi, B.M. Photocatalyst: Mechanism, challenges, and strategy for organic contaminant degradation. In Handbook of Smart Photocatalytic Materials; Mustansar Hussain, C., Mishra, A.K., Eds.; Elsevier: Amsterdam, The Netherlands, 2020; pp. 127-149. ISBN 978-0-12-819049-4.

5. Nasir, A.M.; Jaafar, J.; Aziz, F.; Yusof, N.; Salleh, W.N.W.; Ismail, A.F;; Aziz, M. A review on floating nanocomposite photocatalyst: Fabrication and applications for wastewater treatment. J. Water Process Eng. 2020, 36, 101300. [CrossRef]

6. Gogoi, D.; Namdeo, A.; Golder, A.K.; Peela, N.R. Ag-doped $\mathrm{TiO}_{2}$ photocatalysts with effective charge transfer for highly efficient hydrogen production through water splitting. Int. J. Hydrogen Energy 2020, 45, 2729-2744. [CrossRef]

7. Mollavali, M.; Rohani, S.; Elahifard, M.; Behjatmanesh-Ardakani, R.; Nourany, M. Band gap reduction of (Mo+N) co-doped TiO nanotube arrays with a significant enhancement in visible light photo-conversion: A combination of experimental and theoretical study. Int. J. Hydrogen Energy 2021, 46, 21475-21498. [CrossRef]

8. Bakar, S.A.; Ribeiro, C. Nitrogen-doped titanium dioxide: An overview of material design and dimensionality effect over modern applications. J. Photochem. Photobiol. C Photochem. Rev. 2016, 27, 1-29. [CrossRef] 
9. Changanaqui, K.; Brillas, E.; Alarcón, H.; Sirés, I. ZnO/ $\mathrm{TiO}_{2} / \mathrm{Ag}_{2} \mathrm{Se}$ nanostructures as photoelectrocatalysts for the degradation of oxytetracycline in water. Electrochim. Acta 2020, 331, 135194. [CrossRef]

10. Pishkar, N.; Jedi-soltanabadi, Z.; Ghoranneviss, M. Reduction in the band gap of anodic $\mathrm{TiO}_{2}$ nanotube arrays by $\mathrm{H}_{2}$ plasma treatment. Results Phys. 2018, 10, 466-468. [CrossRef]

11. Gharaei, S.K.; Abbasnejad, M.; Maezono, R. Bandgap reduction of photocatalytic $\mathrm{TiO}_{2}$ nanotube by Cu doping. Sci. Rep. 2018, 8, 14192. [CrossRef]

12. Liu, H.; Gong, H.; Zou, M.; Jiang, H.; Abolaji, R.S.; Tareen, A.K.; Hakala, B.V.; Yang, M. Mo-N-co-doped mesoporous TiO 2 microspheres with enhanced visible light photocatalytic activity. Mater. Res. Bull. 2017, 96, 10-17. [CrossRef]

13. Peng, S.; Yang, Y.; Li, G.; Jiang, J.; Jin, K.; Yao, T.; Zhang, K.; Cao, X.; Wang, Y.; Xu, G. Effect of $\mathrm{N}_{2}$ flow rate on the properties of N doped $\mathrm{TiO}_{2}$ films deposited by DC coupled RF magnetron sputtering. J. Alloys Compd. 2016, 678, 355-359. [CrossRef]

14. Guo, F.; Liu, J.; Zhang, W.; Yu, Z.; Liu, Y.; Liang, W. Synthesis of $\mathrm{Cu}, \mathrm{N}$-doped $\mathrm{TiO}_{2}$ nanotube by a novel magnetron sputtering method and its photoelectric property. Vacuum 2019, 165, 223-231. [CrossRef]

15. Yang, J.; Hu, Y.; Jin, C.; Zhuge, L.; Wu, X. Structural and optical properties of Er-doped $\mathrm{TiO}_{2}$ thin films prepared by dual-frequency magnetron co-sputtering. Thin Solid Films 2017, 637, 9-13. [CrossRef]

16. Kelly, P.J.; Arnell, R.D. Magnetron sputtering: A review of recent developments and applications. Vacuum 2000, 56, 159-172. [CrossRef]

17. De Vietro, N.; Tursi, A.; Beneduci, A. Photocatalytic inactivation of Escherichia coli bacteria in water using low pressure plasma deposited $\mathrm{TiO}_{2}$ cellulose fabric. Photochem. Photobiol. Sci. 2019, 18, 2248-2258. [CrossRef]

18. Sboui, M.; Nsib, M.F.; Rayes, A.; Ochiai, T.; Houas, A. Application of solar light for photocatalytic degradation of Congo red by a floating salicylic acid-modified $\mathrm{TiO}_{2}$ /palm trunk photocatalyst. Comptes Rendus Chim. 2017, 20, 181-189. [CrossRef]

19. Song, J.; Wang, X.X.; Bu, Y.; Zhang, J.; Wang, X.X.; Huang, J.; Chen, J.; Zhao, J. Preparation, characterization, and photocatalytic activity evaluation of $\mathrm{Fe}-\mathrm{N}$-codoped $\mathrm{TiO}_{2} /$ fly ash cenospheres floating photocatalyst. Environ. Sci. Pollut. Res. 2016, 23, 22793-22802. [CrossRef]

20. Wang, B.; Li, C.; Pang, J.; Qing, X.; Zhai, J.; Li, Q. Novel polypyrrole-sensitized hollow $\mathrm{TiO}_{2} /$ fly ash cenospheres: Synthesis, characterization, and photocatalytic ability under visible light. Appl. Surf. Sci. 2012, 258, 9989-9996. [CrossRef]

21. Zhang, J.; Wang, X.; Wang, X.; Song, J.; Huang, J.; Louangsouphom, B.; Zhao, J. Floating photocatalysts based on loading $\mathrm{Bi} / \mathrm{N}$-doped $\mathrm{TiO}_{2}$ on expanded graphite C/C (EGC) composites for the visible light degradation of diesel. RSC Adv. 2015, 5, 71922-71931. [CrossRef]

22. Długosz, M.; Waś, J.; Szczubiałka, K.; Nowakowska, M. TiO ${ }_{2}$-coated EP as a floating photocatalyst for water purification. J. Mater Chem. A 2014, 2, 6931-6938. [CrossRef]

23. Faramarzpour, M.; Vossoughi, M.; Borghei, M. Photocatalytic degradation of furfural by titania nanoparticles in a floating-bed photoreactor. Chem. Eng. J. 2009, 146, 79-85. [CrossRef]

24. Valdez-Castillo, M.; Saucedo-Lucero, J.O.; Arriaga, S. Photocatalytic inactivation of airborne microorganisms in continuous flow using perlite-supported $\mathrm{ZnO}$ and $\mathrm{TiO}_{2}$. Chem. Eng. J. 2019, 374, 914-923. [CrossRef]

25. Shavisi, Y.; Sharifnia, S.; Hosseini, S.N.; Khadivi, M.A. Application of $\mathrm{TiO}_{2}$ / perlite photocatalysis for degradation of ammonia in wastewater. J. Ind. Eng. Chem. 2014, 20, 278-283. [CrossRef]

26. Xue, H.; Jiang, Y.; Yuan, K.; Yang, T.; Hou, J.; Cao, C.; Feng, K.; Wang, X. Floating photocatalyst of B-N-TiO 2 /expanded perlite: A sol-gel synthesis with optimized mesoporous and high photocatalytic activity. Sci. Rep. 2016, 6, 29902. [CrossRef]

27. Sboui, M.; Lachheb, H.; Bouattour, S.; Gruttadauria, M.; La Parola, V.; Liotta, L.F.; Boufi, S. TiO 2 / Ag2O immobilized on cellulose paper: A new floating system for enhanced photocatalytic and antibacterial activities. Environ. Res. 2021, 198, 111257. [CrossRef]

28. Sboui, M.; Nsib, M.F.; Rayes, A.; Swaminathan, M.; Houas, A. $\mathrm{TiO}_{2}-\mathrm{PANI} /$ Cork composite: A new floating photocatalyst for the treatment of organic pollutants under sunlight irradiation. J. Environ. Sci. (China) 2017, 60, 3-13. [CrossRef]

29. Martín de Vidales, M.J.; Nieto-Márquez, A.; Morcuende, D.; Atanes, E.; Blaya, F.; Soriano, E.; Fernández-Martínez, F. 3D printed floating photocatalysts for wastewater treatment. Catal. Today 2019, 328, 157-163. [CrossRef]

30. Singh, S.; Singh, P.K.; Mahalingam, H. Novel Floating $\mathrm{Ag}^{+}$-Doped $\mathrm{TiO}_{2} /$ Polystyrene Photocatalysts for the Treatment of Dye Wastewater. Ind. Eng. Chem. Res. 2014, 53, 16332-16340. [CrossRef]

31. Varnagiris, S.; Medvids, A.; Lelis, M.; Milcius, D.; Antuzevics, A. Black carbon-doped $\mathrm{TiO}_{2}$ films: Synthesis, characterization and photocatalysis. J. Photochem. Photobiol. A Chem. 2019, 382, 111941. [CrossRef]

32. Varnagiris, S.; Urbonavicius, M.; Tuckute, S.; Lelis, M.; Milcius, D. Development of photocatalytically active $\mathrm{TiO}_{2}$ thin films on expanded polystyrene foam using magnetron sputtering. Vacuum 2017, 143, 28-35. [CrossRef]

33. Varnagiris, S.; Urbonavicius, M.; Sakalauskaite, S.; Daugelavicius, R.; Pranevicius, L.; Lelis, M.; Milcius, D. Floating TiO 2 photocatalyst for efficient inactivation of E. coli and decomposition of methylene blue solution. Sci. Total Environ. 2020, 720, 137600. [CrossRef]

34. Kuliesiene, N.; Sakalauskaite, S.; Tuckute, S.; Urbonavicius, M.; Varnagiris, S.; Daugelavicius, R.; Lelis, $\mathrm{M}_{\text {. TiO }}$ application for the photocatalytical inactivation of S. enterica, E. coli and M. luteus bacteria mixtures. Environ. Clim. Technol. 2020, 24, 418-429. [CrossRef]

35. Urbonavicius, M.; Varnagiris, S.; Sakalauskaite, S.; Demikyte, E.; Tuckute, S.; Lelis, M. Application of Floating $\mathrm{TiO}_{2} \mathrm{Photocatalyst}$ for Methylene Blue Decomposition and Salmonella typhimurium Inactivation. Catalysts 2021, 11, 794. [CrossRef] 
36. Singh, P.; Kaur, D. Room temperature growth of nanocrystalline anatase $\mathrm{TiO}_{2}$ thin films by dc magnetron sputtering. Phys. $B$ Condens. Matter 2010, 405, 1258-1266. [CrossRef]

37. Musil, J.; Heřman, D.; Šícha, J. Low-temperature sputtering of crystalline $\mathrm{TiO}_{2}$ films. J. Vac. Sci. Technol. A 2006, 24, 521-528. [CrossRef]

38. Twu, M.J.; Chiou, A.H.; Hu, C.C.; Hsu, C.Y.; Kuo, C.G. Properties of $\mathrm{TiO}_{2}$ films deposited on flexible substrates using direct current magnetron sputtering and using high power impulse magnetron sputtering. Polym. Degrad. Stab. 2015, 117, 1-7. [CrossRef]

39. Kuo, C.G.; Hsu, C.Y.; Wang, S.S.; Wen, D.C. Photocatalytic characteristics of $\mathrm{TiO}_{2}$ films deposited by magnetron sputtering on polycarbonate at room temperature. Appl. Surf. Sci. 2012, 258, 6952-6957. [CrossRef]

40. Chodun, R.; Skowronski, L.; Okrasa, S.; Wicher, B.; Nowakowska-Langier, K.; Zdunek, K. Optical TiO 2 layers deposited on polymer substrates by the Gas Injection Magnetron Sputtering technique. Appl. Surf. Sci. 2019, 466, 12-18. [CrossRef]

41. Loukopoulos, S.; Toumazatou, A.; Sakellis, E.; Xenogiannopoulou, E.; Boukos, N.; Dimoulas, A.; Likodimos, V. Heterostructured $\mathrm{CoO}_{\mathrm{x}}-\mathrm{TiO}_{2}$ Mesoporous/Photonic Crystal Bilayer Films for Enhanced Visible-Light Harvesting and Photocatalysis. Materials 2020, 13, 4305. [CrossRef] [PubMed]

42. NIST. NIST X-ray Photoelectron Spectroscopy Database, NIST Standard Reference Database 20; Version 4.1. Available online: https: / / srdata.nist.gov/xps / (accessed on 24 August 2021).

43. Akhavan, $\mathrm{O}$. Lasting antibacterial activities of $\mathrm{Ag}-\mathrm{TiO}_{2} / \mathrm{Ag} / \mathrm{a}-\mathrm{TiO}_{2}$ nanocomposite thin film photocatalysts under solar light irradiation. J. Colloid Interface Sci. 2009, 336, 117-124. [CrossRef] [PubMed]

44. Akhavan, O.; Ghaderi, E. Photocatalytic reduction of graphene oxide nanosheets on $\mathrm{TiO}_{2}$ thin film for photoinactivation of bacteria in solar light irradiation. J. Phys. Chem. C 2009, 113, 20214-20220. [CrossRef]

45. Akhavan, O.; Abdolahad, M.; Abdi, Y.; Mohajerzadeh, S. Synthesis of titania/carbon nanotube heterojunction arrays for photoinactivation of E. coli in visible light irradiation. Carbon N. Y. 2009, 47, 3280-3287. [CrossRef] 